Informasi - ISSN (p) 0126-o650; ISSN (e) 2502-3837

Vol. 5o, No. 2 (2020), pp. v-x doi: http://doi.org/10.21831/informasi.v5oi2.36847

\title{
Editorial
}

\section{Will technology take over journalism?}

\author{
Ni Made Ras Amanda Gelgel \\ Udayana University, Indonesia \\ rasamanda13@unud.ac.id
}

In November 2020, South Korea News Channel shocked the world by introducing An Artificial Intelligent AI-Powered News Anchor. The Channel has an AI-powered anchor to allow the stations to broadcast news $24 / 7$, especially when the human news anchor might be asleep or sick. This AI-powered anchor call AI-Kim, a facsimile of a human news anchor named Kim Ju-ha. It copies her look, facial animation, and even her mannerisms. AI- Kim, in her introduction, said that she was able to report news precisely the way that anchor Kim JuHa does.

Journalism never thought that a robot or AI-powered could replace a news anchor. News anchors are supposed to be delivering news by analyzing it, giving some comments to the audience about the news to make the audience have an insightful thought, and giving more context in the news, not just seeing and reading the news. But what happened in South Korea put Journalism, especially news anchors, in a crucial spot. Can machines or robots replace them? Even the real Kim Ju-Ha feels concerned that someday AI-Kim will threaten her position as news-anchor (Kyodonews.net, 2020). AI-Kim appears four times a day to deliver the main news of the country. Because AI-Kim is computer-based, it doesn't need to sleep like a human to stay healthy.

AI-Kim is not the first AI-powered news anchor. In 2019, China's Xinhua News Agency debuted the world's AI news anchor known as Xin Xiaomeng. By 2020, Xinhua's AI news anchor has published 3,400 reports with 10.000 minutes length in total. This number is higher than a human news anchor can accomplished (Techtimes.com, 2020). Both AI-powered news anchors believed will be able to take on a higher role in the future of journalism and the newsroom.

AI-news anchor is proof of the advancements in information and communication technologies (ICTs). Advanced ICTs have an impact in numerous fields, including journalism. It is not just in AI-powered news anchors, but the use of advanced technologies has influenced all the journalism processes, starting production, distribution, and consumption. (Biswal \& Gouda, 2020). Technologies change the way of life, including media and journalism. Will technologies change journalism? Will it be extinct? Before AI-powered news anchors were published, Newspaper journalism was already in a crisis state (Picard, 2006). Newspaper journalism faces declining circulation and revenues, convergence media, conglomerate ownership, and new technology (Reinardy, 2011). 
Besides technologies, other aspects have contributed to making journalism in a state of crisis. Nolleke, Maares, \& Hanusch (2020) stressed three inter-connected keys as crucial in a journalism state of crisis. There are technological disruption, economic constraints, and societal attitudes.

\section{TECHNOLOGICAL DISRUPTION}

Technological disruption has become the most considerable contribution to this state of crisis (Franklin, 2012). It also endangered the existence of journalists in the new era (Deuze, 2005). Practices of journalism are also being affected, both individually or professionally. Before AI-News anchor, technologies already impacted journalism by automated journalism. Calrson (2015) stressed that automated journalism is the most potentially disruptive in journalism. Automated journalism is algorithmic processes that convert data into narrative news texts with limited to no human intervention. These advanced technologies of machinewritten news texts led the new expansive news content beyond human journalists' capabilities. This invention makes a new issue concerning the future of journalists and the newsroom. Automated journalism or robot journalism implies practical, sociopolitical, psychological, legal for journalists, news organizations, and audiences (Montal \& Reich, 2016).

The advancement of technology was threatening not just the role of journalists but news business models too (Sjovaag, 2016). Sjovaag (2016) studied paywall strategies of news business models, advanced technologies support online news content in highly traffic-generating, but these strategies limited readers to read the news unless they pay. Highly traffic-generating due to communication technologies transformation make newsroom never sleep. Online media, for example, needs speed to deliver news and information every second. It's making the newsroom worked $24 / 7$ without taking a break. This high pressure is causing journalists were working overloaded (Seethaler, 2017) and make journalists and newsroom fatigue and stress (Reinardy, 2011).

\section{ECONOMIC CONSTRAINTS}

Media, as an economic institution, make them have to gain revenue and benefit to survive. Economic trends have made most of the media less independent. Media have adopted some solutions such as debt, cost reduction, outsourcing, and finding new revenue sources (De Mateo, Berges, \& Gamatxe, 2010). Economic pressures media corporation to cut their budgets that make the workforce in journalism insecure. The rapid change in the news industry and threats of layoffs, buyouts, and media closing have led journalists to experience job insecurity and worry about their long-term futures in journalism (Ekdale et al., 2015).

Being a journalist nowadays was not considered to be a promising profession. Economic globalization makes journalism a high-level insecurity job. (De Mateo, Berges \& Garnatxe, 2010). The only journalist who works in mainstream media or national media has a high salary, which is not easy to conquer (Hummel, 2012). It is also happening in Indonesia, and it is not easy to become a journalist in mainstream media or national media. In local media, Journalists work without an employment agreement, without health assurance or retirement allowance. Being a journalist is mean ready to lose your jobs or having no career (Cohen, Hunter \& O’Donnell, 2019). Cohen, Hunter, \& O’Donnell (2019) studied a journalist in Canada who lost his job and career nowadays working in a different condition such as freelance, contract, and part-time. This shift in employment status from full-time, secure, and wellremunerated work demonstrates underlying precariousness in journalism in general, not just in Canada. Job insecurity makes journalists unlikely to upgrade their practices and reticent to initiate change. It makes journalism practice not develop. (Ekdale et.al, 2015) 


\section{SOCIETAL ATTITUDES}

Societal attitudes see media become in a state of crisis. The study reported that public trust in media and journalism is declining (Fink, 2018; Kiousis, 2001). Based on the 2018 Reuters Institute Digital News Reports, most people in most countries distrust the news media. People distrust the media because of various factors dan structural conditions inside the news organizations like technological, economic, and political that shape media roles, routines, and revenue models. (Lewis, 2019). The Report shows in Finland and Portugal that 62 percent of the people can trust the media most of the time, but in South Korea and the number is just 25 percent of the people. In general, the number of people who trust in news media only 49 percent (Newman et al., 2018). By Kiousis (2001), a study in America put newspapers as news media with the highest credibility, followed by online news and television news.

Fink (2018) pull out that this lack of trust has been getting worse. She recorded some reasons, and there are (1) decreasing resources to produce quality journalism due to of traditional news business model (Rosenstiel \& Mitchell, 2004) (2) the increasing form of sensationalized news and' clickbait' (Brants, 2013) (3) as the impact of people distrust the government and (Jones, 2004) (4) Media are being controlled by some powerful institutions or people with their agendas. (Newman \& Fletcher, 2017).

Newman \& Fletcher (2017) had a study to describe the reasons for low trust in the news media and social media across nine countries. They don't trust the news media is related to bias, spin, and agendas. The public see that influential people are using the media for their agendas, both economic or political interests. News media were not representing people in common. They see media from this perspective dominated by young people.

\section{WHY SHOULD JOURNALISM LIVE?}

According to Kovach \& Rosenstiel (2001), journalism's value is a commitment to truth. It gives voice to the voiceless, provides a forum for public criticism, monitors power, and serves the public good independently. These sacred hopes have to live to make the society well informed. Journalism should not lose their attributes that include neutrality, objectivity, and fairness (Deuze, 2005). New Technology should enhance journalism in news gathering and dissemination (Russial. Laufer, \& Wasko, 2015). Journalism is not a machine; it's an art and craft with professional responsibilities, to see reality with fresh eyes and heart that machine can't do. But with technologies, journalists will be upgrading the news by delivering news in high quality, multi-platform, and digital technologies upgrading the newsroom to be more powerful and positively impact humanity and humankind.

\section{REFERENCES}

Biswal, S. K. \& Gouda, N. K. (2020). Artificial intelligence in journalism: A boon or bane? In A..J. Kulkarni, A. J., \& Satapathy, S. C. (2020). Optimization in machine learning and applications. Singapore: Springer. https://doi.org/10.1007/978-981-15-0994-0_10

Brants, K. (2013). Trust, cynicism, and responsiveness. In: Peters, C \& Broersma, M (eds) Rethinking journalism: Trust and participation in a transformed news landscape. London: Routledge.

Carlson, M. (2015). The robotic reporter: Automated journalism and the redefinition of labor, compositional forms, and journalistic authority. Digital Journalism 3(3). 416-431. DOI: https://doi.org/10.1080/21670811.2014.976412

Cohen, N. S., Hunter, A., \& O’Donnell, P. (2019). Bearing the burden of corporate restructuring: Job loss and precarious employment in Canadian journalism. Journalism Practice, 13(7), 
817-833. DOI: https://doi.org/10.1080/17512786.2019.1571937

De Mateo, R., Bergés, L., \& Garnatxe, A. (2010). Crisis, what crisis? The media: business and journalism in times of crisis. tripleC: Communication, Capitalism \& Critique. Open Access Journal for a Global Sustainable Information Society, 8(2), 251-274. DOI: https:// doi.org/10.31269/triplec.v8i2.212

Deuze, M. (2005) What is journalism? Professional identity and ideology of journalists reconsidered. Journalism 6(4),442-464. DOI: https://doi.org/10.1177/1464884905056815

Ekdale, B., Tully, M., Harmsen, S., \& Singer, J. B. (2015). Newswork within a culture of job insecurity: Producing news amidst organizational and industry uncertainty. Journalism Practice, 9(3), 383-398. DOI: https://doi.org/10.108o/17512786.2014.963376

Fink, K. (2018). The biggest challenge facing journalism: A lack of trust. Journalism 20(1): 4043. DOI: doi.org/10.1177/1464884918807069

Franklin, B. (2012). The future of journalism: Developments and debates. Journalism Studies 13(5- 6), 663-681. DOI: https://doi.org/10.1080/1461670X.2012.712301

Hummel, R., Kirchhoff, S., \& Prandner, D. (2012). "We used to be queens and now we are slaves" working conditions and career strategies in the journalistic field. Journalism Practice, 6(56), 722-731. DOI: https://doi.org/10.1080/17512786.2012.667276

Jones, D. A. (2004). Why Americans don't trust the media: A preliminary analysis. Harvard international journal of press/politics, 9(2), 60-75. DOI: https://doi. org/10.1177/1081180X04263461

Kiousis, S. (2001). Public trust or mistrust? Perceptions of media credibility in the information age. Mass communication \& society, 4(4), 381-403. DOI: https://doi.org/10.1207/ S15327825MCSo404_4

Kovach, B. \& Rosenstiel, T. (2001). The elements of journalism. New York: Random House.

Kyodonews.net. (2020). AI-powered virtual news anchor comes to South Korean TV. https:// english.kyodonews.net/news/2020/11/5fc3c846c868-ai-powered-virtual-news-anchorcomes-to-s-korean-tv.html

Lewis, S. C. (2020). Lack of trust in the news media, institutional weakness, and relational journalism as a potential way forward. Journalism, 21(3), 345-348. DOI: https://doi. org/10.1177/1464884918807597

Montal, T., \& Reich, Z. (2017). I, robot. You, journalist. Who is the author? Authorship, bylines and full disclosure in automated journalism. Digital Journalism, 5(7), 829-849. DOI: https://doi.org/10.1080/21670811.2016.1209083

Newman, N \& Fletcher, R. (2017). Bias, bullshit and lies: Audience perspectives on low trust in the media. Report, Reuters Institute for the Study of Journalism, University of Oxford, Oxford, November. Available at: http://reutersinstitute.politics.ox.ac.uk/our-research/ bias-bullshit-and-lies-audience-perspectives-low-trust-media

Newman, N., Fletcher, R., \& Kalogeropoulos, A. (2018). Reuters Institute for the study of journalism, University of Oxford. Digital News Report, Oxford: UK. Available at: https:// reutersinstitute.politics.ox.ac.uk/sites/default/files/digital-news-report-2018.pdf

Nölleke, D., Maares, P., \& Hanusch, F. (2020). Illusio and disillusionment: expectations met or disappointed among young journalists. Journalism, 1464884920956820. DOI: https:// doi.org/10.1177/1464884920956820

Picard, R. G. (2006). Capital crisis in the profitable newspaper industry. Nieman Reports, 6o(4), 
10-12.

Reinardy, S. (2011). Newspaper journalism in crisis: Burnout on the rise, eroding young journalists' career commitment. Journalism, 12(1), 33-50. DOI: https://doi. org/10.1177/1464884910385188

Rosenstiel, T., \& Mitchell, A. (2004). The impact of investing in newsroom resources. Newspaper Research Journal, 25(1), 84-97. DOI: https://doi.org/10.1177/073953290402500107

Russial, J., Laufer, P., \& Wasko, J. (2015). Journalism in crisis? Javnost-The Public, 22(4), 299312. DOI:10.1080/13183222.205.1091618

Seethaler, J. (2017). New worlds of journalism: How Austrian, German and Swiss journalists perceive innovation and change. Journalism report $V$ : Innovation and transition, 53-67.

Sjøvaag, H. (2016). Introducing the Paywall: A case study of content changes in three online newspapers. Journalism Practice, 10(3), 304-322. DOI: https://doi.org/10.1080/17512786.2 015.1017595

Techtimes.com. B., Urian. (2020). First AI news anchor in South Korea: How does it compare to China's 'Xinhua'? source: https://www.techtimes.com/articles/254712/20201203/ainews-anchor-south-korea-accomplishes-10-ooo-minutes-reporting.htm 
